\title{
LINGUISTIC ABILITIES FOR MASTERING FOREIGN LANGUAGES IN STUDENT TRANSLATORS WITHIN SIOP MODEL
}

\author{
Tetiana Yefymenko ${ }^{1}$ \\ Myroslava Maistrenko ${ }^{2}$
}

DOI: https://doi.org/10.30525/978-9934-26-069-8-4

Abstract. The purpose of the paper is to identify linguistic abilities to master foreign languages in students-translators. This research was conducted based on the methods and methodology of observation, comparison, analysis, functional and descriptive methods. In order to solve this problem, the achievements of linguistics, sociolinguistics, psychology, psycholinguistics, methods of teaching foreign languages were analyzed, as the study of the phenomenon of linguistics ability is based on them. Linguistic ability includes some specific abilities such as foreign language ability, language guessing, language intuition and communication skills. The result is the formation of a linguistic personality, in particular, the bilingual personality of the translator in a dialogue that has the ability and skills to use the language in all its manifestations in different situations of intercultural communication; the ability to understand and assimilate someone else's way of life and behavior in order to break ingrained stereotypes; skills to expand the individual picture of the world by involving in the «language picture of the world» speakers of the studied language. Value/originality. The development of language abilities is possible on the basis of individualization, differentiation of the learning process and increasing motivation for learning a language. It is necessary to clarify that the presence of communication skills, linguistic intuition and ability to languages is absolutely not enough for a full-fledged foreign language communication, and even more so for characterizing a secondary linguistic personality, in fact, its development is the leading goal of teaching a

\footnotetext{
${ }^{1}$ Candidate of Philological Sciences, Associate Professor of Philology Faculty, V.O. Sukhomlynskyi Mykolaiv National University, Ukraine

${ }^{2}$ Doctor of Philology, Professor of Philology Faculty,

V.O. Sukhomlynskyi Mykolaiv National University, Ukraine
} 
foreign language for translation students. Linguistic giftedness and ability for languages are only a prerequisite for the formation of intercultural competence and the development of a secondary linguistic personality.

\section{Introduction}

In modern linguistics, the problem of linguistic abilities is especially relevant, due to several reasons. First, the value system of the people, way of life, mentality, national character, traditions, customs - all this, along with the real world around man, the real conditions of his life is reflected in language. Knowledge of the state system, social economic relations, norms and rules of conduct, style and way of life, rituals in various situations of interpersonal and business partnership, customs, traditions of native speakers are the key to the success of intercultural communication and correct presentation of the material. Secondly, in the context of modern integration of the individual international and world culture, and in the context of expanding international contacts, internationalization of all spheres of life, the problems of language, culture, communication and translation are urgent. Thus, there is a need to study the identifying of multilevel interference in intercultural communication and translation.

To establish contacts between domestic organizations and foreign partners, citizens of Ukraine were forced to review the training of translators. When communicating with foreign partners, it is necessary not only to know a foreign language, but also to have the right linguistic skills to experience the cultural characteristics of their partners, if interlingual communication is conducted in a professional field and involves oral or written translation from one language to another.

Thus, correct intercultural communication and their future activities depend on the correct use of linguistic abilities by students-translators.

Knowledge of foreign languages is not only an important aspect of the development of a full-fledged member of society, but also, at the present stage of human development, helps to determine a professional orientation, expand scientific horizons and succeed in work. It is difficult to overestimate the social and cultural significance of learning a foreign language, especially in the modern period of the formation of young states in the international arena. All this led to a rethinking of the role of a foreign language as an important and necessary means of intercultural 
communication. Knowledge of a foreign language in the modern world is one of the most important components of a modern successful person; a foreign language is increasingly acquiring the status of a socio-economic and political mechanism of mutual understanding between various representatives of the world community in various spheres of their life. Knowledge of at least one foreign language broadens one's horizons, allows one to learn about the culture and customs of another people. That is why the study of the problems of the development of «linguistic abilities» are promising and relevant for modern science.

\section{The concept of «ability»}

The concept of "ability" is defined as "1) a unique combination of abilities that ensures successful performance; talent; 2) mental potential, a holistic individual characteristic of cognitive abilities and learning abilities. Presence of inclinations for the development of abilities" [2, p. 196]. The inclinations, on the one hand, are genetically determined, on the other hand, they are dependent on the activity of the individual and the surrounding social space. Often, abilities are considered inclinations and vice versa.

The linguistic ability of students is "An increased level of ability to accelerate the processes of thinking in a foreign language, to active cognitive activity in the field of theory and history of language, to creativity in the choice of methods of communication in a foreign language, to sustainable motivation in learning the language" [13].

Speaking about extraordinary abilities, manifested in the rapid, solid learning of foreign languages and fluency in them, as a rule, they use such concepts as «a sense of language», «language abilities», «communication skills», «foreign language abilities», «language guess», «Linguistic intuition», «ability to foreign languages.» They designate the constituent components and conditions for the manifestation of linguistic giftedness, are interdisciplinary and are considered in pedagogy, psychology, linguodidactics, psycholinguistics.

\section{Concepts that characterize linguistic abilities, and are extraordinary for the study of foreign languages}

«A sense of language» - Emotional feeling of consistency / inconsistency, harmony in the language, understanding of the systemic properties of the 
language, accompanying the process of generation and perception of speech. It arises as a result of subconscious generalization of numerous speech acts [2].

«Language abilities» - Individual psychological characteristics, expressed in the speed and ease of acquiring linguistic knowledge, the rules of analysis and synthesis of language units that allow you to build and analyze sentences, use the language system to solve communication problems [8].

«Communication skills» - Abilities, personality traits, ensuring the effectiveness of her communicative activities, primarily communication with other individuals, and psychological compatibility in activities [2].

«Language guess» - The ability to reveal the meaning of an unfamiliar word (phrase) through the context; is based on the use of knowledge in the field of word formation, the ability to understand already known polysemous words in new meanings, on the knowledge of international words of the native and studied languages [2].

«Linguistic intuition» - Immediate understanding of words and speech structures that have not yet been encountered in the recipient's speech experience. There is a comparison of the encountered unit with some set standards in long-term memory [2].

«Ability to foreign languages» - Ability to use various systems of symbolic forms that perform the function of communication [8].

\section{Characteristics of linguistic ability}

- cognitive abilities in different ways correlate with aspects of language (this explains the asymmetry observed in the study of a foreign language in the success of mastering one or another aspect of the language or the type of speech activity);

- abilities for foreign languages include a set of abilities that ensure, first of all, the mastery of linguistic aspects (phonetics, grammar, vocabulary) and types of speech activity (reading, writing, speaking, listening);

- linguistic ability determines the readiness to understand and produce speech;

- linguistic ability, linguistic guess and sense of language are subject to development;

- language abilities are a specific psychophysiological mechanism that is formed on the basis of neurophysiological prerequisites; 
- the development of language abilities occurs on the basis of the accumulation of speech experience, as a result of speech activity and under the influence of social influences.

The versatility and ambiguity of abilities for foreign languages is recognized by the majority of researchers, whose area of scientific interests is related to the study of methods for diagnosing and developing these abilities, as well as issues of the formation of a linguistic personality. On the one hand, the ability must be considered in conjunction with a complex of specific subject abilities. At the same time, from a number of definitions of general ability contained in terminological dictionaries of psychology and pedagogy, it follows that general ability, being the basis for the development of special abilities, is a factor independent of these abilities.

\section{Different scientific views on linguistic abilities}

A certain versatility and ambiguity of abilities for foreign languages (linguistic abilities) is evidenced by the great variability of the complexes of the structure of abilities called by various researchers that determine the success of mastering a foreign language. Let's consider a number of them below.

M.K. Kabardov claims that linguistic abilities consist of communicative and cognitive abilities, the ratio of which is the predominance of one or another component and determines its type of mastering a foreign language. Communication skills ensure effective interaction and adequate mutual understanding in the communication process; characterize the qualitative and quantitative characteristics of the exchange of information, perception and understanding of another person, the development of an interaction strategy. Cognitive abilities - the ability to accumulate and systematize information, to analytically isolate the patterns of linguistic phenomena. They include gnostic skills, cognitive skills associated with the peculiarities of attention, thinking and memory; perception and adequate understanding of various kinds of sign systems: verbal (mainly) and non-verbal; the ability to form and formulate thoughts; the ability to identify and understand the lexical and grammatical aspects of the language [8].

G.I. Bogin talks about level indicators qualities of language ability correctness, speed, richness, which is the richness of the vocabulary and grammatical forms, an adequate choice of linguistic forms, an adequate synthesis of the whole text [4]. 
E.I. Passov considers the abilities for cognitive activity, the ability for emotional-evaluative activity, the ability to carry out productive and reproductive speech actions to be especially important for the successful study of foreign languages [2].

Z.N. Nikitenko names the abilities necessary and essential for cognitive development: «1) foreign language ability associated with the development of phonetic, lexical and grammatical means of foreign language communication; 2) foreign language speech ability associated with the independent construction of statements when speaking and writing and with understanding foreign language speech by ear and reading; 3) cognitive abilities that determine the formation of foreign language speech activity: the ability to phonological awareness of foreign language speech, working memory, attention and probabilistic forecasting» [11].

E.G. Azimov and A.N. Shchukin believe that when teaching a foreign language, abilities significantly depend on the level of hearing, memory, and verbal thinking. It seems that they can be attributed to the inclinations [2].

A.I. Yatsikevichus considers the sensitivity of the hearing aid to be important; productivity of verbal memory; the ability to notice and change the structural variations of the language [17].

L.I. Sidorenkova in the first place in the structure of linguistic abilities puts verbal intelligence (fast, competent and fluent speech with correct pronunciation and intonation pattern), followed by a high level of proficiency in speech activity (speech readiness, linguistic and speech activity, variability of the choice of linguistic means and ways for their adequate application, mobility of using language and speech means in accordance with the speech context) and cognitive processes (perception, memory, thinking and imagination). The central link in the structure of linguistic abilities is verbal and logical thinking [14].

American scientists (John B. Carroll, Stanley Sapon) have identified four groups of special cognitive abilities that underlie the successful acquisition of a foreign language:

1. Mechanical associative memory (rote as-sociational) - is necessary for mastering a large number of arbitrary connections between words and their meanings, which must be mastered.

2. The ability to phonetic coding (phonetic coding ability) the perception of sounds of a foreign language and sound forms of words 
and expressions, their «encoding» in long-term memory and reproduction as needed.

3. Grammatical sensitivity - the ability to perceive grammatical relations in a foreign language and understand the role of grammar in generating and translating utterances and sentences.

4. Inductive ability - general cognitive ability, the ability to see and deduce the rules governing the formation of stimulus patterns [15].

Thus, students-translators' abilities for foreign languages are characterized at least by the level of cognitive abilities, verbal intelligence, and the ability of productive and reproductive speech activity.

It is curious that researchers actually bypass the topic of inability to foreign languages. Most of them agree that complete inability to learn a foreign language is extremely rare [2, p. 182]. Practitioners of the educational process, on the contrary, often attribute failures in language learning to learning disabilities. Learning ability means receptivity to learning, accumulation of experience, depends on ability. The ease and pace of mastering heterogeneous knowledge, the breadth of their transfer to new conditions depends on learning [12, p. 382].

\section{Influence of human age characteristics}

Experimental studies and analysis of scientific literature indicate that the ability of students-translators to teach a foreign language largely depends on the age-related characteristics of mental development.

Linguistic scientists rightly argue that only teaching based on nerve connections can help preserve what has been learned for a long time, that language learning presupposes the presence and further development of the psychological and mental abilities of the learners.

They pay attention to the study of the individual characteristics of students in order to develop their inherent abilities for various aspects of the language, because Knowing more about the characteristics of each of them, it is easier to achieve better results. In their opinion, at a certain stage, trainees should even be grouped according to their individual characteristics in order to implement a differentiated approach to teaching.

The theoretical setting of L.S. Vygotsky [6] about the actual development and the zone of proximal development is true in relation to any stage of human mental development and gives an indication of the relatively 
unlimited possibilities of human mental development. The psychological content of adolescence is associated with the development of self-awareness, the solution of specific tasks of professional self-determination and entry into adulthood. In early adolescence, cognitive and professional interests, the need for work, the ability to make life plans, social activity are formed, the independence of the individual is affirmed, the choice of a life path.

In youth, a person asserts himself in the chosen business, acquires professional skill, and it is in his youth that professional training is completed. During this period of life, a person is as efficient as possible, withstands the greatest physical and mental stress, and is most capable of mastering complex methods of intellectual activity. The easiest way is to acquire all the knowledge, skills and abilities necessary in the chosen profession, and competencies are formed. The required specific, special personal and functional qualities are developed, such as organizational skills, initiative, courage, resourcefulness, necessary in a number of professions, clarity and accuracy, speed of reactions, etc.

A student as a person of a certain age and as a person can be characterized from three sides:

1) from the psychological side, which is the unity of psychological processes, states and personality traits;

2) social, in which social relations are embodied, the qualities generated by the student's belonging to a particular social group;

3) biological, which includes the type of higher nervous activity, the structure of the analyzers, unconditioned reflexes, instincts, physical strength, physique, etc.

The age of 18-20 years is the period of the most active development of moral and aesthetic feelings, the formation and stabilization of a person's character. At this age, it is especially important to master the full range of social roles of an adult: civil, professional and labor, etc. This period is associated with the beginning of «economic activity», by which demographers understand the inclusion of a person in independent production activities, the beginning of a work biography and the creation of his own family. The transformation of motivation, the entire system of value orientations, on the one hand, the intensive formation of special abilities in connection with professionalization, on the other hand, highlight this age as the central period in the formation of character and intelligence. This is 
the time of sports records, the beginning of artistic, technical and scientific achievements [16].

Student age is also characterized by the fact that during this period the optimal peak of the development of intellectual and physical forces is reached. But they often appear «Scissors» between these possibilities and their actual implementation. The time of study at the university coincides with the second period of adolescence or the first period of maturity, which is characterized by the complexity of the formation of personality traits [1]. A characteristic feature of moral development at this age is the strengthening of conscious motives of behavior. The qualities that were lacking in full in the senior grades are noticeably strengthening - dedication, determination, perseverance, independence, initiative, and the ability to control oneself. Interest in moral issues such as goals, lifestyle, duty, love, fidelity, etc. increases.

At the same time, specialists in the field of developmental psychology and physiology note that a person's ability to consciously regulate his behavior at the age of 17-19 is not fully developed. Frequent unmotivated risk, inability to foresee the consequences of their actions, which may not always be based on worthy motives. So, V.T. Lisovskiy notes that 19-20 years is the age of selfless sacrifices and complete dedication, but also of frequent negative manifestations. The formation and functioning of mental processes at the age of 17 to 22 years largely depends on how the contradiction between the level of educational activity, which has developed and consolidated among young people during their studies in secondary school, and the requirements that educational activity makes at the university are overcome. If this contradiction is resolved taking into account the patterns of development of mental activity, then students cope with the requirements that are presented to them [16].

Perception at the student age is manifested mainly in its arbitrary form - in the form of observation, wholly subordinating itself to the tasks of educational activity. Cognitive activity is characterized by a high level of generalization and abstraction, the ability to argue, prove the truth or falsity of individual provisions, link them into a system. The student's mental activity fulfills a new, personal function.

The formation of theoretical thinking leads to the fact that it begins to mediate a young person's attitude to the world. It is thanks to this that 
a worldview is formed. Features of memory and attention at this age are associated with a general tendency towards purposefulness, arbitrariness and self-regulation of all mental activity. An essential feature is the high selectivity and differentiation of both attention and memory, their conditioning by the goals, tasks, interests and attitudes of the personality of young people [16].

The individual characteristics of a person that have developed by the student age - from the manifestations of the basic properties of the type of temperament to the breadth of associations, flexibility of mental activity or the volume of working memory - can have a significant impact on the dynamics and success of work.

Individual differences in speech activity in a foreign language, associated with the characteristics of the student's memory, are numerous and varied. Memory is traditionally called one of the main components of linguistic abilities and the most important process for the success of language ability. The research results indicate a significant outstripping of memory development in senior school age, and in the student years, that is, in the third decade, there is a decline in the productivity of short-term memory. Differences in the preservation of logically related material appear in both age characteristics and types of memory. For example, mechanical retention slows down towards student's age. With age, figurative meaningful memorization also begins to play a large role. However, there is not only an increase, but also a decrease or decrease in individual properties. So, with age, the difference in memorizing visual and verbal material decreases, an inverse relationship is observed in the development of figurative voluntary and figurative involuntary memorization. While the productivity of figurative voluntary memorization increases with age, figurative involuntary memorization tends to decrease.

An extremely important factor determining the development of positive individual characteristics of memory in speech activity is an increase in the importance of memorization, an increase in its subjectively assessed importance. In the practice of forming types of speech activity in a foreign language, it is necessary to follow the principle of active operation with educational material to be memorized. Moreover, if involuntary memorization is carried out under the influence of new, bright, emotionally significant factors and without a goal set in advance by students, then it 
is useful to provide such conditions in the educational process that would facilitate the use of this type of memorization. In this case, it is necessary to take into account the relationship between voluntary and involuntary memorization of speech material.

The problem of taking into account both age and individual psychological characteristics of students requires increased study, and teaching students a foreign language largely depends on the age characteristics of mental development. That is, it can be concluded that linguistic abilities are closely interrelated with the intellectual abilities and age characteristics of the individual.

The cognitive components of linguistic abilities are considered as a complex mental formation, which is characterized by a stable dynamic structure that combines interpenetrating mental, mnemonic, and perceptual components that have reached a certain level of development at a student age. Linguistic abilities are considered as the main individual psychological factor contributing to the acquisition of a foreign language by students. In the psychology of teaching foreign languages, the first attempts to identify linguistic abilities date back to the sixties [1, p. 310].

Researchers identify several types of language abilities. Phonetic abilities, which are characterized by the success of mastering the phonetics of a foreign language. Lexical abilities, which are largely determined by the development of verbal-figurative (auditory, visual) and motor memory, contributing to the strong memorization of the sensory basis of the word. Distinguishing words that are similar in any respects, catching semantic differences between words of a foreign language, as well as native and foreign languages, quick recognition and understanding of words in the perception of speech in a foreign language, quick search for the necessary foreign words to express their own thoughts - is also the area of responsibility lexical abilities.

Grammatical abilities are associated with recognizing various parts of speech and members of sentences, capturing the etymological structure of foreign words and their morphological features, the ability to change words and the structure of a phrase according to the rules of grammar, etc. Stylistic abilities include correct and quick generalization of the lexical and grammatical features of a particular language style, and then the ability to recognize different styles and their reproduction in their own oral and written speech, etc. [3]. 
J.B. Carrol identifies seven factors that are decisive for success in learning a foreign language, and linguistic abilities themselves are reduced to the following: phonetic coding, which is the ability to encode phonetic material in such a way that it can be recognized, identified and memorized for some time; the ability to master grammar, i.e. forms of language and their organization in expression, mechanical memory in the assimilation of linguistic phenomena, expressed in the ability to learn a sufficient number of associations in a limited period of time, inductive linguistic ability to assimilate linguistic forms, rules and samples of linguistic material with minimal assistance.

At the same time, under the foreign language ability of J.B. Carrol understands a relatively stable individual characteristic, consisting of various structural components or abilities. P.Pimsleurdivides all the factors contributing to the acquisition of a foreign language into motivational, intellectual and personal (individual), which combine, to some extent, the first two groups: associative memory, features of articulation, auditory discrimination, interest in the language being studied. At the same time, both authors highlight the main factors - motivation and verbal intelligence, which, in turn, influence everyone else. Thus, foreign researchers identify the following parameters that contribute to mastering a foreign language: motivation, the amount of material that needs to be studied; the amount of memory, the time required for study, the ability to imitate sounds, sociability, individual-typological personality traits, intelligence, age of students, teaching methods, attitude to the language being studied, psychological attitude.

The researchers believe that the most productive direction in the study of linguistic abilities in psychology and methods of teaching foreign languages is the establishment of the ability to learn a foreign language, based on the qualities of the course of interdependent mental processes: thinking, imagination, memory, perception, etc. Abilities are based on the qualities of mental processes that reach a high level of development and are relatively stable personality traits. Separate mental cognitive processes in real activity act collectively, as a functional organ.

Learning abilities, being one example of the interaction of general and special abilities, are considered general mental abilities for the assimilation of knowledge. These abilities are understood as the system of the intellectual properties of the personality, the forming qualities of the mind, on which the 
productivity of educational activity depends. Domestic scientists introduce the concept of «learning», as a summary indicator of which is «economics of thinking», which is the result of the level of development of such intellectual properties as the generalization of mental activity, its awareness, flexibility, independence and stability. The properties listed above determine the rate of advancement in mastering educational activities.

I.A. Winter distinguishes three levels in the study of language ability or individual psychological factors: at the physiological level, at the level of performance results and at the psychological level, and the latter is considered as the most promising and fruitful, since it is associated with the study of mental processes such as thinking, memory, perception and peculiarities of their course [7].

A.A. Leont'ev believes that behind the expression «ability to a foreign language» is a group of the following factors: differences in the type of higher nervous activity and the characteristics of the course of mental processes; differences in memory, perception, thinking; differences in personality traits associated with communication [9]. Linguistic thinking means a way of orientation in verbal material based on linguistic images concepts. Linguistic thinking and feeling for language are based on various types of linguistic generalization. The level of development of linguistic thinking is associated with theoretical generalization, the sense of language with empirical generalization [5].

Personal qualities of a person that contribute to the success of activities (in our case, the acquisition of a foreign language) can be considered components of abilities, but not basic, but optional. Psychologists have found that sociable and emotional students learn a foreign language more easily. Consequently, it is legitimate to include the emotional and communicative qualities of students in the structure of foreign language abilities. However, one should take into account the fact that abilities, as mental qualities of a person, are a rather conservative formation - their development is slow, requires patience, great efforts and concerted actions on the part of the teacher and the student. In addition, the level of development of abilities depends on the inclinations - the natural characteristics of the nervous system and the brain.

Their role is that, «firstly, they determine different ways and means of the formation of abilities. Secondly, they affect both the level of a person's 
achievements in any area and the speed of development of abilities» [3]. In the structure of special abilities, an important place should be occupied by the corresponding motivation, focus on mastering the desired profession. It is quite obvious that without a proper motive, it is extremely difficult to realize even the very rich potential of attention, memory and psychomotor skills. Developing foreign language abilities, improving them, one should pay the necessary attention and purposeful formation of motivation for mastering linguistic activities.

Speaking about the structural organization of speech activity, first of all, it should be noted that any activity, including speech, has a threelevel structure. It includes incentive-motivational, orienting-research and executive phases. The first phase is realized by a complex interaction of needs, motives and the purpose of the action as a desired result. The source of speech activity in all its types is the communicative-cognitive need and, accordingly, the communicative-cognitive motive. The motive determines the dynamics and nature of all types of speech activity.

V. Nechyunas is one of the authors studying personality traits that meet the requirements of foreign language speech activity. In its structure, personal qualities and attitudes are in the first place: 1) a penchant for language; 2) the productivity of verbal memory; 3) auditory articulation sensitivity; 4) the mobility of verbal associations; 5) the ability to establish linguistic patterns [10]. Of foreign psychologists, the motivational factor in the structure of foreign language abilities includes P. Pimsleur, however, he does not place it in the first place, but nevertheless defines it as a necessary component of this structure: verbal intelligence, interest in learning a foreign language, auditory ability, such as difference of sounds and sound-letter connection.

Of course, «abilities» are not limited to knowledge, skills and abilities, but ensure their rapid acquisition, consolidation and effective use in practice [16]. Thus, the concept of «ability» is used to characterize people in whom a certain function is manifested much wider than it is usual [3]. Human abilities have a multilevel nature, and therefore are based on the corresponding inclinations, require systematic and persistent exercises that condition their development, suggest the individual's attitude to them as a means of solving vital problems [4, p. 425]. So, if abilities develop in the presence of appropriate inclinations, then we can assert that linguistic abilities are no exception. 
Linguistic ability is a complex dynamic structure, the ratio of the components of which changes with age and level of foreign language proficiency. Linguistic abilities include both general features of mental activity - flexibility and mobility of thought processes - and special features of speech foreign language activity inherent in a person studying a foreign language [7]. They can also be considered as the main mechanisms of speech activity, are equally manifested in the development of any language [7]. Linguistic abilities are characterized by: the ability to accelerate the processes of thinking in a foreign language, creativity in choosing methods of communication in a foreign language, stable motivation to learn a foreign language, the ability to use the knowledge gained in new contexts, etc.

The ability of different people differs not only in the level of manifestation, but also in quality, i.e. his individuality, since abilities do not just coexist with each other, but acquire a new character depending on the presence and degree of development of other abilities [3, p. 105]. Modern researchers consider ability as a high level of giftedness development, which is accompanied by high achievements in a certain field of activity [10, p. 119]. And when the level of development of special abilities is high, it is said about special giftedness [4, p. 425]. In the views of various scientists, the phenomenon of giftedness is ambiguous. So, according to B.M. Thermal «ability is a qualitatively unique combination of abilities, on which the possibility of achieving greater or lesser success in performing a particular activity depends» [11].

\section{Conclusions}

Linguistic abilities are not a one-factorial, but a complex dynamic structure consisting of many substructures, the ratio of components in which changes with age and level of foreign language proficiency.

The main components of linguistic abilities are: the level of development of sensory-perceptual differential sensitivity (auditory and visual) in speech activity, the volume of verbal mechanical and semantic memory, logical thinking, associative thinking, the ability to anticipate language elements, flexibility of transformation processes.

Thus, linguistic abilities as a complex dynamic structure have such characteristics as flexibility, variability, plasticity, and, therefore, amenable to influence. Correctly selected material, taking into account the individual 
and age characteristics of the student and the methodological competence of the teacher will help develop the student's linguistic abilities, improve them.

Therefore, the aim of our research is the linguistic ability in the aspect of learning foreign languages by translation students. We came to the conclusion that it is the level of mastery of foreign languages that can fully demonstrate the level of development of a person's linguistic ability. It is also worth noting that it is possible to talk about the development of linguistic abilities only if a person at a high level speaks more than one language, that is, at least one more language besides the native one.

Going beyond what is covered in the publication questions, we add that there are still many debatable issues in the development of linguistic abilities for foreign languages: the possibility of individualization and differentiation of language education, the validity and necessity of teaching languages from an early age, new approaches to the development and support of gifted student translators, «side effects» polylingualism and early teaching of foreign languages, non-test methods for identifying linguistic ability, the presence of a direct dependence of the ability to learn a foreign language on the ability to master the native language, the innate nature of linguistic ability.

\section{References:}

1. Ananiev B.H. (1962) Pro spivvidnoshennia zdibnostei i obdarovanosti [About the ratio of abilities and talents]. Moscow: APN RRFSR, p. 15-42.

2. Azimov E.H., Shchukin O.M. (1999) Slovnyk metodychnykh terminiv (teoriia i praktyka vykladannia mov) [Dictionary of methodical terms (theory and practice of language teaching)]. St. Petersburg: Zlatoust, p. 472.

3. Bieliaiev B.V. (1965) Narysy z psykholohii navchannia inozemnym movam [Essays on the psychology of learning foreign languages]. Moscow: Prosvitnytstvo, p. 28.

4. Bohin H.I. (1980) Suchasna linhvodydaktyka [Modern linguodidactics]. Kaliningrad: KDU, p. 61.

5. Borovyk A.A., Hokhlerner M.M. (1976) Do vysnovku pro rozvytok pochuttia movy $\mathrm{v}$ protsesi navchannia neridnii movi [To the conclusion about the development of a sense of language in the process of learning a foreign language]. Psychology Kharkiv, vol. 9, no. 132, pp. 70-76.

6. Vyhotskyi L.S. (1956) Myslennia i mova [Thinking and language]. Moscow: APN RRFSR, p. 519.

7.Zimniaia I.A., Vedeniapyn Yu.A., Tolkachova S.D. (1988) Doslidzhennia faktoriv, shcho obumovliuiut uspishnist navchannia movlennia inozemnoiu movoiu [Research of factors that determine the success of foreign language learning]. Moscow: Moscow University, pp. 3-6. 
8. Kabardov M.K. (2001) Komunikatyvni ta kohnityvni skladovi movnykh zdibnostei (indyvidualno-typolohichnyi pidkhid) [Communicative and cognitive components of language abilities (individual-typological approach)] (PhD Thesis), Moscow: Moscow University.

9. Leontiev A.A. (1985) Psykholohichni peredumovy rannoho ovolodinnia inozemnoiu movoiu [Psychological prerequisites for early mastery of a foreign language]. Foreign languages at school, no. 5, pp. 24-29.

10. Nechiunas V.Iu. (1971) Pro vyvchennia komponentiv inshomovnykh zdibnostei [About studying the components of foreign language abilities]. Tbilisi, p. 333 .

11. Nikitenko Z.M. (2011) Teoriia i tekhnolohiia rozvyvaiuchoho inshomovnoi osvity v pochatkovii shkoli [Theory and technology of developing foreign language education in primary school] (PhD Thesis), Nizhniy Novgorod, p. 45.

12. Pedahohika (2005) [Pedagogy]. Minsk: The modern word, p. 720.

13. Rumiantseva M.V. (2006) Navchannia linhvistychno obdarovanykh shkoliariv inozemnoi movy $\mathrm{v}$ umovakh dodatkovoi osvity [Teaching linguistically gifted students of a foreign language in the conditions of additional education] ( $\mathrm{PhD}$ Thesis), St. Petersburg, p. 188.

14. Sydorenkova L.I. (2008) Vikovi vidminnosti v strukturi movnykh zdibnostei i mozhlyvosti yikh obliku v protsesi navchannia inozemnoi movy [Age differences in the structure of language abilities and the possibility of taking them into account in the process of learning a foreign language]. Psychology of learning, no. 10 , p. $14-28$.

15. Zdibnosti do inozemnykh mov [foreign language aptitude]. Human psychology. URL: http://www.psibook.com/20/17/96

16. Chernomorova O.M. (2005) Indyvidualno-psykholohichni ta vikovi osoblyvosti studentiv pid chas navchannia inozemnoi movy [Individual psychological and age characteristics of students while learning a foreign language]. Moscow: PFC notifications, p. 143.

17. Yatsikevichus A.I. (1970) Psykholohiia formuvannia bahatomovnosti [Psychology of multilingualism formation] (PhD Thesis), Vilnius, p. 54. 